\title{
Past, Present and Future use of Municipal Water and Freshwater Resources of the Bekkersdal Community, Westonaria, South Africa
}

\author{
Simone L. Liefferink ${ }^{* 1}$, Elize S. van Eeden ${ }^{2}$, Victor Wepener ${ }^{3}$ \\ ${ }^{1}$ School of Biological Sciences, North-West University, 11 Hoffman Street, 2531 Potchefstroom, \\ South Africa \\ e-mail: simone.liefferink@gmail.com \\ ${ }^{2}$ School of Basic Sciences, North-West University, Hendrik van Eck Blvd, 1900 Vanderbijlpark, \\ South Africa \\ e-mail: Elize.vanEeden@nwu.ac.za \\ ${ }^{3}$ School of Biological Sciences, North-West University, 11 Hoffman Street, 2531 Potchefstroom, \\ South Africa \\ e-mail: Victor.Wepener@nwu.ac.za
}

Cite as: Liefferink, S. L., van Eeden, E. S., Wepener, V., Past, Present and Future use of Municipal Water and Freshwater Resources of the Bekkersdal Community, Westonaria, South Africa, J. sustain. dev. energy water environ. syst., 5(3), pp 430-446, 2017, DOI: http://dx.doi.org/10.13044/j.sdewes.d5.0155

\begin{abstract}
Water is a human right which is recognised globally, with an increasing focus being placed on the ethical considerations of water use. The paper focuses on investigating access and perceptions surrounding this basic need in the Bekkersdal community and the Wonderfonteinspruit, in the Gauteng Province, South Africa. It is hypothesised that several challenges exist both internally and externally in the process of ensuring the right to water in Bekkersdal, from both an environmental and service provision perspective. Through the use of a questionnaire conducted with a statistically representative group from the Bekkersdal community, the following issues were investigated: current water use of municipal and river water, challenges regarding water availability and quality, perceptions regarding the state of the Wonderfonteinspruit and future water use wants and needs. The results indicate a strong reliance on municipal water complicated with water service delivery issues, which resulted in $10 \%$ of the residents making use of the polluted Wonderfonteinspruit on a regular basis. Furthermore, the need for solutions to water supply and availability solutions should be developed in conjunction with community members. This research represents some of the first steps that need to be taken to do so.
\end{abstract}

\section{KEYWORDS}

Water availability, Communities, Human rights, Provision of water, Wellbeing, Sustainable environments.

\section{INTRODUCTION}

Ethical considerations associated with water use and management as a topic of study has become more urgent and intensive in recent times. This is demonstrated by several authors such as Falkenmark and Folke [1] who investigated the ethics of socioecohydrological catchment management based on human rights and the need to maintain

\footnotetext{
* Corresponding author
} 
a sustainable environment. Llamas [2] considered the management of water from the ethical considerations based on the value systems of a society. Rahaman and Varis [3] indicated the need to practice Integrated Water Resource Management with ethical considerations forming part of this process, while Amery [4] explore the religious ethics associated with water management in the Islamic faith. This is necessitated due to the urgency of securing water for everyday use, especially freshwater which is required for economic and social development as well as to satisfy basic human rights [5]. The Universal Declaration of Human Rights [6] provides for the basic right to life and dignity. In this regard water should be considered as essential for human life and therefore is indivisible as a basic need to fulfil the right to life and dignity. The requisite need for water to support human life and development is proposed to be linked with basic human rights on several levels such as under cultural and religious traditions [7] as well as through connecting technical, scientific and engineering approaches with the human right to water [8]. Despite the absolute need for water to sustain human life and the economy it is evident globally that water pollution remains a serious threat to freshwater resources even in protected areas [9]. Water abundant countries such as Europe have realised that they may not be immune to economic, social and environmental implications of water shortages, such as those faced in Africa [10].

Ordinarily the ethical concerns with regards to water management and availability within a social context will revolve around issues of: basic rights to life, dignity and provision of basic needs, water as a common and shared good, the rights and responsibilities related to water access, the economic importance of water as well as the environmental and ecological impacts of such activities and finally, the importance of water in terms of human health and wellbeing [2]. These issues will be discussed in the context of the community of Bekkersdal in terms of their use and observations of the Wonderfonteinspruit and municipal water.

Bekkersdal has recently been labelled as one of the most controversial and violence driven communities in South Africa. Furthermore, what is concerning within this context is that South Africa itself has been dubbed the 'protest capital of the world' [11]. Records show service protests in Bekkersdal dating back to the 1970's and 1990's [12]. From these reports it would suggest a community striving for an improvement in their living conditions. The latest history of Bekkersdal (especially the informal section) has been riddled with social and political unrest. News media has reported on a number of service delivery strikes [13] and violent occurrences within Bekkersdal [14], such as the destruction of property [15].

Therefore based on the need expressed in recent literature to further explore the ethical considerations of water management, as well as the serious concerns faced by the Bekkersdal community, there is need to understand the ethical considerations of water management within the community. The aims of the study are to determine, by means of ethical considerations and through the perspective of the community members, whether the rights of the people of Bekkersdal are being upheld with regards to water availability, as well as the impact of the natural environment on their health and wellbeing. It is hypothesized that there will be limitations in providing for the rights of the people of Bekkersdal with regards to water use and that the natural environment with regards to the Wonderfonteinspruit will be seen from a negative perspective and regarded as unimportant to their present and future health and wellbeing.

\section{METHODS AND MATERIALS}

The methods for conducting the study were divided into several distinct categories as presented below: study site selection, questionnaire composition, selection of fieldworkers, conducting the questionnaire and finally statistical analyses of the results. 
The methods followed chronologically as per the order below. Careful consideration was given for the methods applied in each section.

\section{Study site}

The community of Bekkersdal falls into the Westonaria Municipality which is situated in the West Rand Districts Municipal region and is located in the Gauteng Province of South Africa as can be noted in Figure 1. It comprises of a formal $( \pm 3,313$ households) and informal ( $\pm 13,000$ households) section, with areas of the informal section bordering the Donaldson Dam which forms part of the Wonderfonteinspruit [16]. The areas considered to be informal are: Mandelaville, Winnie/Holomisa, Silver City, Spook Town, Thambo and X-section. The formal area includes Bekkersdal Proper and Skierlik. Mandelaville and Winnie/Holomisa are the closest to Donaldson Dam and the formal section is one of the areas furthest away from the dam.

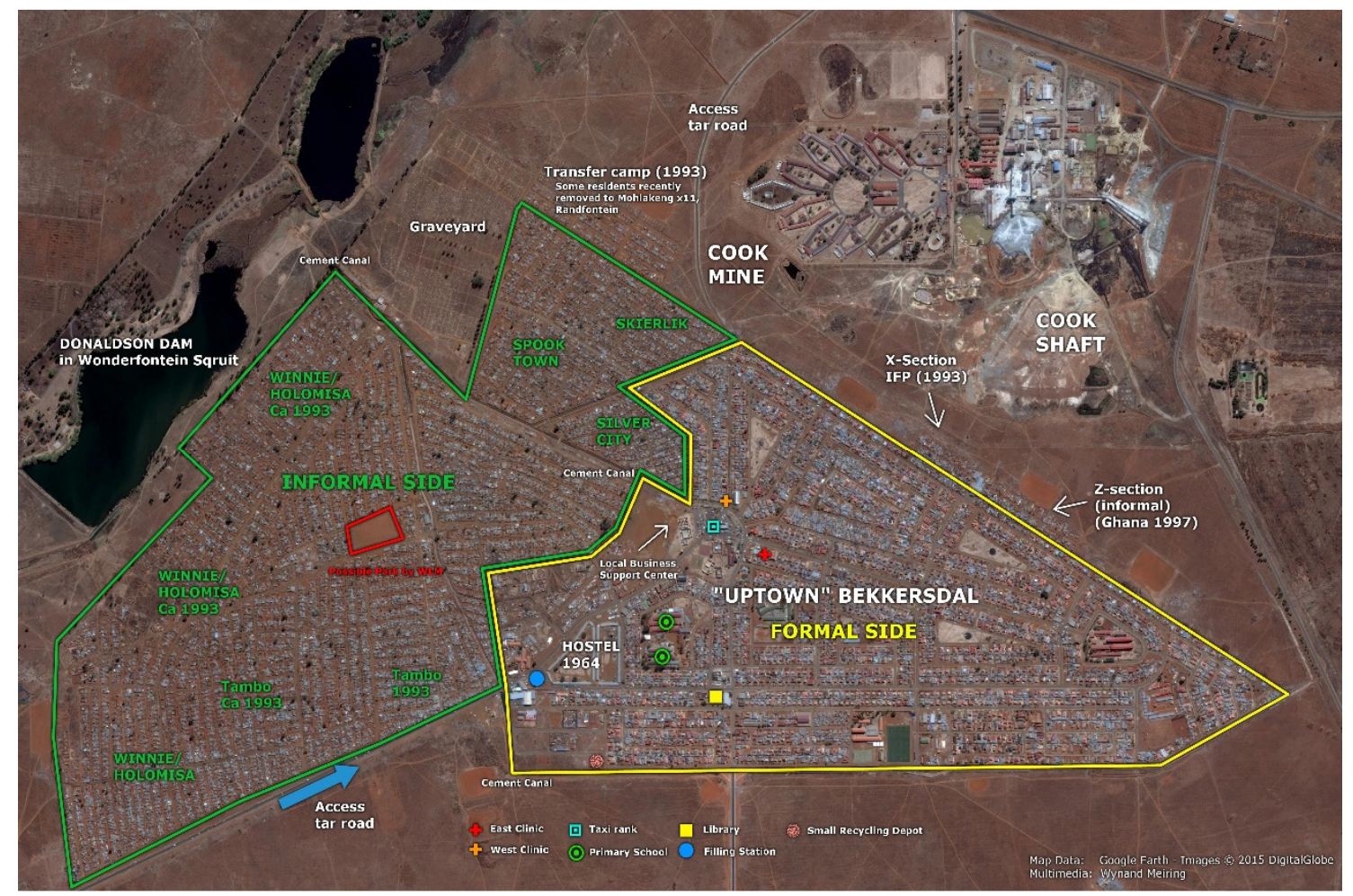

Figure 1. Map of Bekkersdal and Donaldson Dam [11]

\section{Composition of questionnaire}

The questionnaire entitled Questionnaire on: Water use of the UpperWonderfonteinspruit by the people of Bekkersdal was composed based upon baseline research that has been previously conducted within the Bekkersdal community, especially bearing in mind the level of education and language competency of individuals within the Bekkersdal community [11]. The baseline research was conducted with the intention to cover the research needs of several disciplines. The questionnaire of the current study was developed as a more focussed effort to compliment the aforementioned baseline research such that a more in-depth understanding of the Bekkersdal community's sense of water needs, understanding and availability in their environment could be established. This study's questionnaire was thoroughly reviewed by knowledgeable experts and was divided into the following sections: demographic details, current water and future use of the Wonderfonteinspruit, water quality perceptions of the Wonderfonteinspruit and field notes. 


\section{Selection of fieldworkers}

The fieldworkers chosen for this study were selected from individuals that had assisted with the broader project's baseline questionnaire within the Bekkersdal community in 2013. These individuals were taken from home-based care workers as was arranged with the local municipality. Each had to meet the following criteria: be able to read and write English, minimum of Grade 10 and able to interpret the questionnaires. All fieldworkers were Bekkersdal residents in order to compliment the community engagement focus related to the project, so as to put the participants at ease and allow for open and honest answers. For this study the fieldworkers received two training sessions on the questionnaires so as to introduce them to the questions and allow them to study the questionnaire and provide ideas for corrections or recommendations. Thereafter, the participants were interviewed as follows: each fieldworker performed a mock interview where they were asked to translate some of the questions into the anticipated South African languages within Bekkersdal, to answer queries that may be asked by the interviewees and to explain what they understood about some of the questions. From this effort and outcome the ten best performing fieldworkers were chosen from the larger group to assist with the fieldwork survey.

\section{Conducting questionnaire surveys}

This project will comply with the ethics mandate of the greater NRF project (see Ethical Clearance: no. FH-BE-2013-0014). The fieldworkers were divided into groups of two such that the fieldworkers could assist one another and to provide for their own safety. Each group was assigned a section of Bekkersdal each week with a stipulated number of questionnaires. The number of questionnaires per section was based upon the size of the section, for example Mandelaville was a large section and a total of 115 questionnaires were conducted while $\mathrm{X}$-section was a small section and only 50 questionnaires were conducted. In the sections of an appropriate size every fifth house was interviewed while in the even smaller sections every second house was interviewed, such that a representative sample from each section could be attained. Each week the fieldworkers returned to the researcher the allotted number of questionnaires from the previous week and received the next allotted number of questionnaires, but on the provision that all the questionnaires were correctly filled in and completed. As expected some questionnaires did not fulfil the desired standards and were discarded but the sample size of 642 questionnaires, of the original 650 questionnaires, was large enough however to still provide a statistically representative sample. Additionally, semi-structured interviews with the fieldworkers and key community leaders [17], both prior and subsequent to the questionnaire research were conducted such that the relevance of the questionnaires were confirmed and a better interpretation of the answers by the researchers could be gained, that was invaluable to the interpretation of the results.

\section{Statistical analyses}

The statistical program, SPSS was used to determine the relationships between the questionnaire outcomes. The Phi-coefficient and Cramér's V analysis was used to determine the association between binary and nominal variables respectively within the questionnaire results. In order to determine the likelihood of the observed relationships determined by the Phi-coefficient and Cramér's V analysis, the Pearson's chi-square test was applied. The interpretation of the practical significance of the Phi-coefficient and Cramér's V was performed as per Ellis and Steyn [18], which uses a measure of the effect size based on the spread of data. A small effect is $p=0.2$, medium $p=0.5$ and a large effect $p=0.8$. 


\section{RESULTS}

The respondents were made up of $38.62 \%$ formal households and $61.37 \%$ informal households in order to equally represent the profile of Bekkersdal. The household dynamics with regards to employment status were divided into $64.73 \%$ dependents and $35.27 \%$ providers with households showing a $74.29 \%$ unemployment rate, with only $18.11 \%$ being employed on a full time basis (Figure 2).

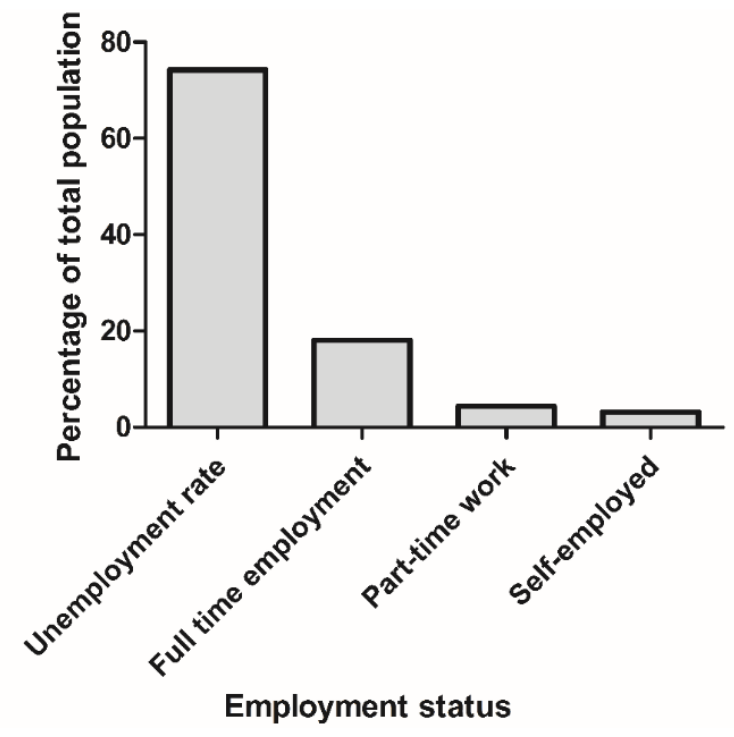

Figure 2. Employment status of households in Bekkersdal for 2014

All households indicated that their main source of water is municipal water when available. Some $96.4 \%$ of the formal residents and $30.9 \%$ of informal residents indicated that collecting water from municipal taps was very easy (minimum effort required), while the majority of the informal households indicated that collecting water was difficult $(45.2 \%)$ to extremely difficult $(8.9 \%)$ to collect (Figure 3$)$. A strong relationship was found, according to the Phi-coefficient $(\varphi)(p=0.652)$, between the differences in perceptions in the formal and informal settlements, regarding the difficulty involved in collecting water. The Pearson Chi-square test showed that the statistical difference was relevant.

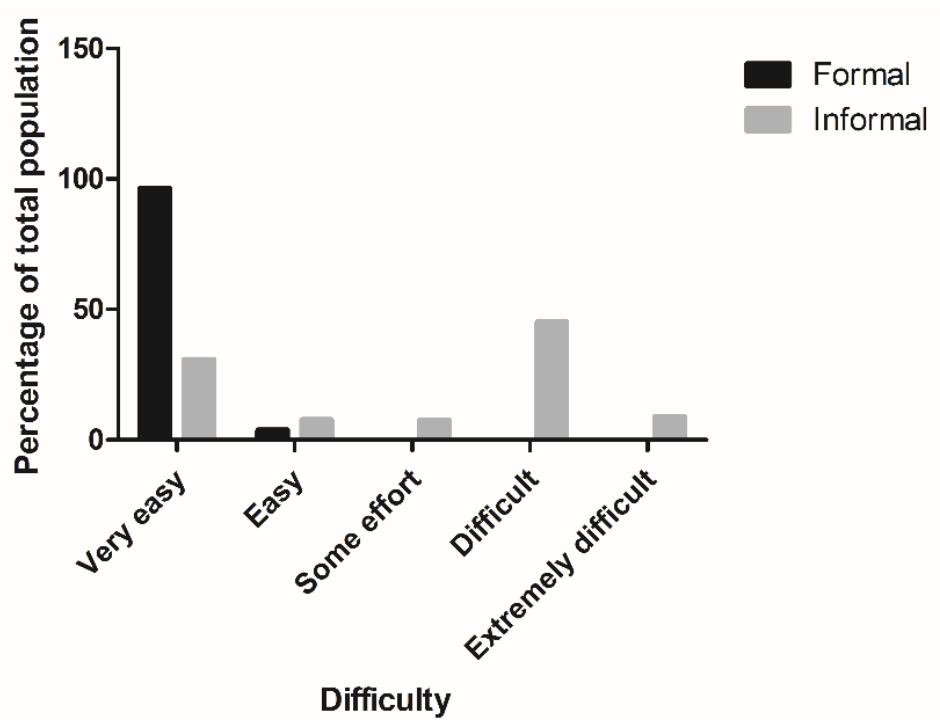

Figure 3. Difficulty involved in collecting water by households in Bekkersdal 
Similarly, differences between the formal and informal households with regards to distance travelled to collect water can be noted. Almost exclusively, 99.6\% of the formal households indicated that collecting water from the municipal water supply took less than five minutes while the majority of informal respondents indicated that collecting water from the municipal water supply took between 6-15 minutes $(35.20 \%)$ or more than 20 minutes (38.37\%) (Figure 4).

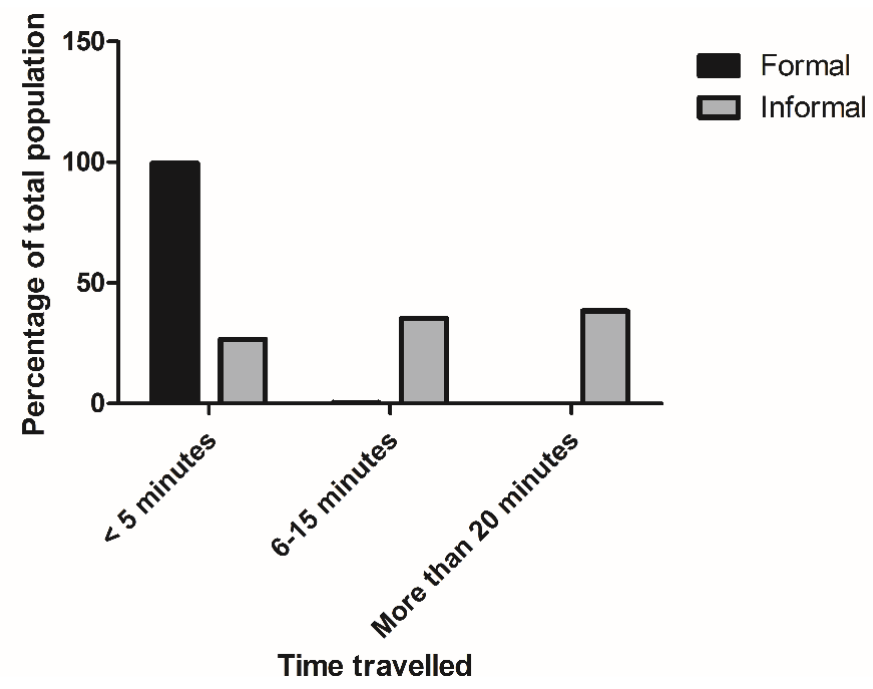

Figure 4. Distance travelled to collect water for the households of Bekkersdal

Residents indicated that most of them (54.70\%) could collect water on a daily basis while some (44.20\%) had continuous access to water within their homes (Figure 5). The Phi-coefficient $(\varphi)$ indicated a strong relationship between the differences in the time taken to collect water $(p=0.715)$ and the periodicity of access to water $(p=0.884)$ as compared to the informal or formal status or the household. This relationship was considered to be statistically significant as per the Pearson Chi-square.

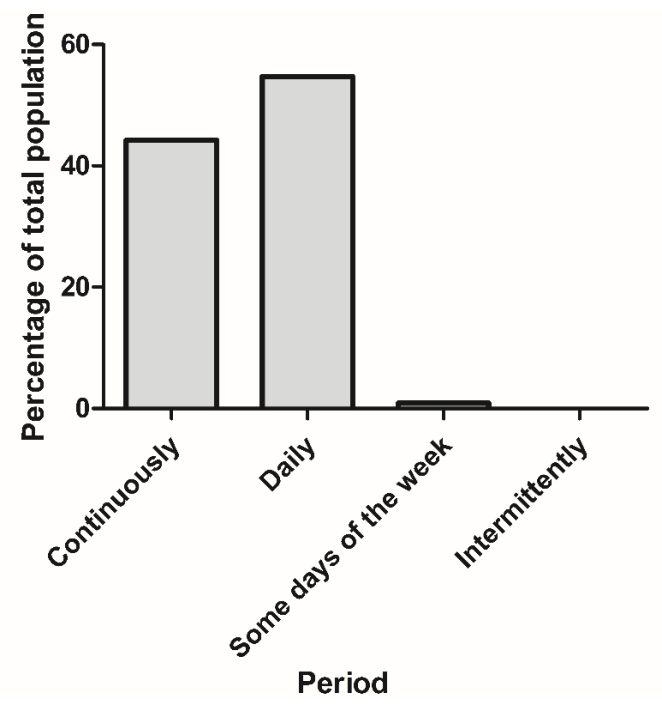

Figure 5. Periodicity of access to water

Yet the majority of respondents, 70.09\% indicated that problems have occurred and continue to occur in Bekkersdal with regards to water service delivery by the municipality. Individuals often had multiple complaints and in total 539 separate complaints were noted that were divided into seven distinct categories as can be noted in Figure 6. Of the 539 
complaints $25.42 \%$ were related to payment issues, $23.56 \%$ to taps being few and/or far away, $22.63 \%$ were regarding municipality closing water services without informing the community, $15.40 \%$ complained about broken taps, $9.28 \%$ were distressed about the long queues to collect water, $2.60 \%$ indicated the problems associated with burning shacks and the lack of water to extinguish the fires and $1.11 \%$ claimed to have no water. Other concerns not included in this summary but that have been mentioned is the lack of security resulting in broken pipes, the need to collect water from mines when water is unavailable in Bekkersdal and the health impacts of water especially when the Donaldson Dam is used as an alternative water source. Reasons for the strike in 2013 were identified as being as a result of the unwillingness of unemployed residents to pay for the water services and the limitations in the availability of taps thus leading to residents having to walk long distances and wait in queues to collect water (Table 1).

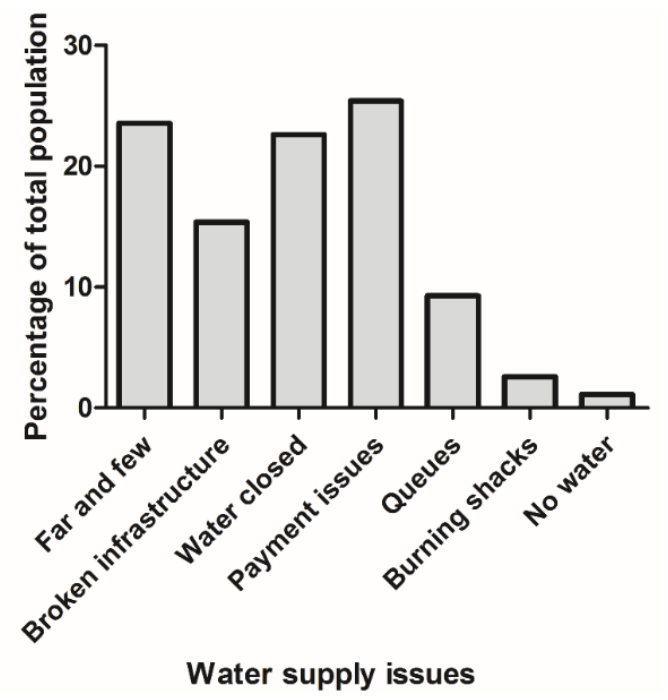

Figure 6. Past and current complaints about water delivery

Table 1. Quotes from the Bekkersdal survey regarding issues with water service delivery in the community

\begin{tabular}{|c|c|}
\hline Issue & Quote \\
\hline Paying for water services & $\begin{array}{l}\text { In the past few months there was a toy-toy here in Bekkersdal } \\
\text { because the municipality want the residents to pay for water }\end{array}$ \\
\hline Taps are far and too few & The resident had to travel to collect water with a swollen foot \\
\hline $\begin{array}{l}\text { Water services } \\
\text { infrastructure broken }\end{array}$ & $\begin{array}{l}\text { Water from the taps is running in the street, most are dumping } \\
\text { dirty water into the street and the streets become dirty and smell } \\
\text { bad, which causes sickness in the community }\end{array}$ \\
\hline $\begin{array}{l}\text { Water closed without } \\
\text { informing the community }\end{array}$ & $\begin{array}{l}\text { The municipality closes the water and do not inform } \\
\text { the residents and they only get water after } 5 \text { PM, they do not } \\
\text { care about the residents }\end{array}$ \\
\hline $\begin{array}{l}\text { Long queues for access } \\
\text { to water }\end{array}$ & $\begin{array}{l}\text { Have to wait in very long queues for hours to get water and the } \\
\text { taps are very far from our houses }\end{array}$ \\
\hline Burning shacks & $\begin{array}{l}\text { Burning of shacks because the water taps are too far away to } \\
\text { stop the fires }\end{array}$ \\
\hline No water & $\begin{array}{c}\text { There is no water so the residents use water from the Donaldson } \\
\text { Dam and that causes stomach diseases }\end{array}$ \\
\hline
\end{tabular}

The Bekkersdal households indicated that $10.14 \%$ make use of the Donaldson Dam (as part of the Wonderfonteinspruit) as their principal source of water, though the use of river water was almost equally split between the formal and informal settlements, as 
indicated by the weak Phi-coefficient $(\varphi)$ of $p=-0.143$. A greater percentage indicated they make use of the Donaldson Dam when water services are unavailable or as a supplement water for other activities. Most of the Wonderfonteinspruit users either continuously $(7.17 \%)$ or occasionally $(6.70 \%)$ drink the water from the Donaldson dam (Figure 7). The next most frequent use of the dam is for washing. Some $4.52 \%$ of the respondents indicated that they use the water continuously for washing (Figure 7). Other uses also included irrigation, watering of livestock, recreation and religious practices.

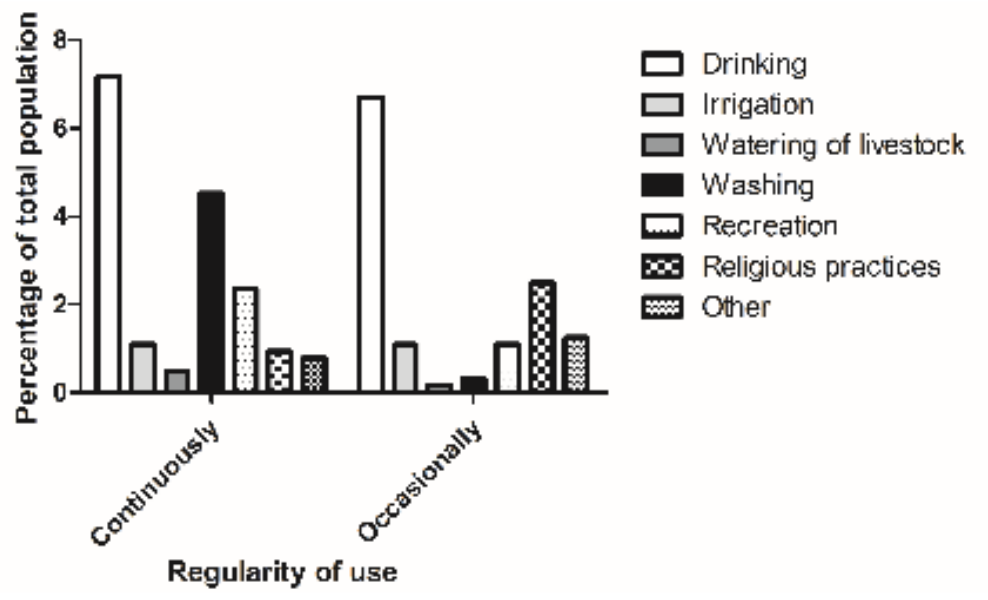

Figure 7. Use of the Upper-Wonderfonteinspruit (inclusive of the Donaldson Dam) for various activities

Health effects from generally using the water in the Wonderfonteinspruit were experienced by $11.54 \%$ of the respondents. These can be divided into diarrhoea $(45.45 \%)$, skin problems $(33.77 \%)$ and drowning $(6.49 \%)$ and other afflictions $(14.29 \%)$ such as pest problems from mosquitoes, unsavoury smells, effects from mining chemicals and general reference to people dying as a result of the water (Figure 8). The groups that were seen to make most use of the dam were identified to be traditional healers $(35.45 \%)$, unemployed residents $(25.60 \%)$ and fishermen (23.01\%) (Figure 9). Most respondents indicated that they do not fish in the Dam however some $4.5 \%$ do fish in Donaldson dam (Figure 10) while it was also mentioned that some residents purchase resources from fishermen fishing in the Dam. In total some $54.84 \%$ of the respondents were aware that resources from the Donaldson Dam were being sold. Fish and mud cakes were the most commonly identified resources being sold.

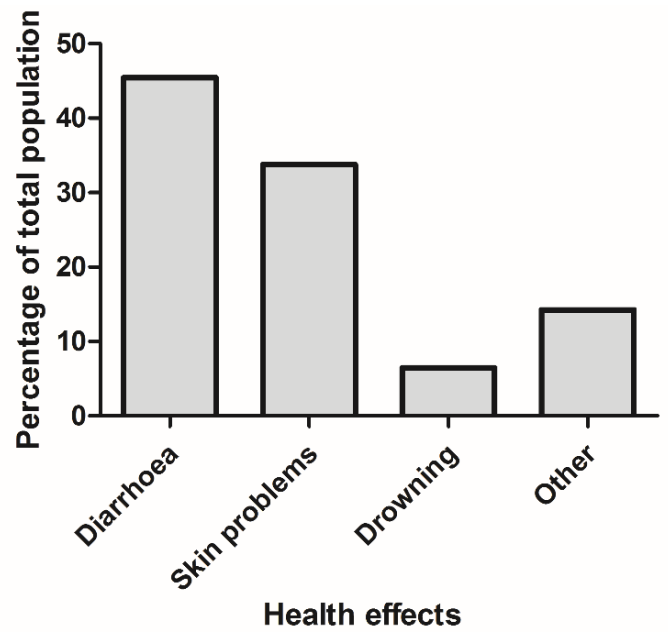

Figure 8. Health effects caused by the use of Donaldson Dam 


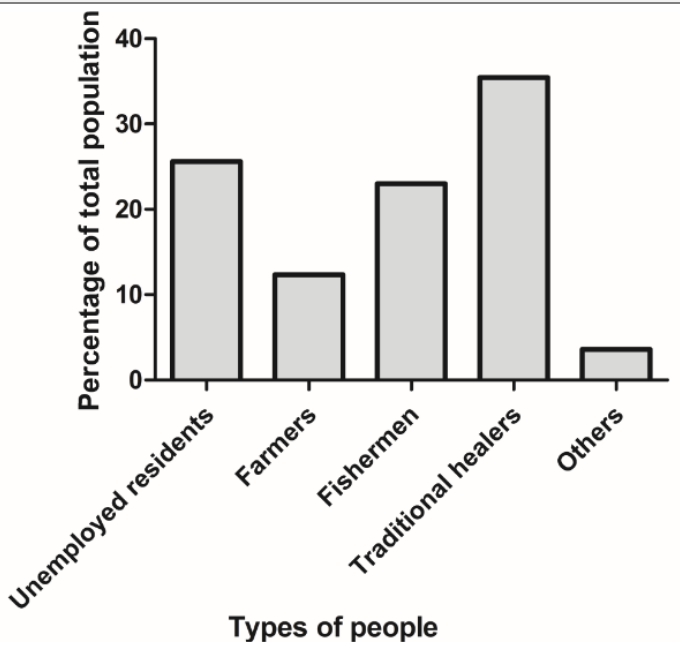

Figure 9. Persons identified as most commonly using the Donaldson Dam

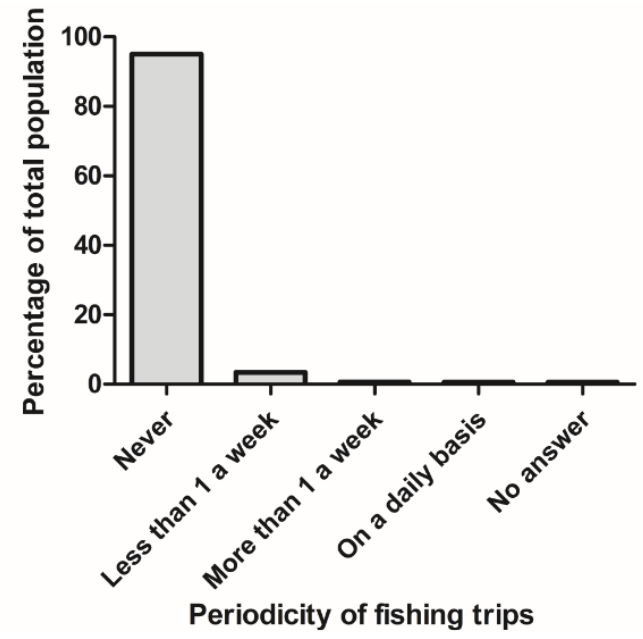

Figure 10. Fishing for food and income in the Donaldson Dam

As can be noted in Figure 11, the respondents indicated that they would use the Donaldson Dam for the following activities if it was in a better state: drinking (22.02\%), irrigation $(25.45 \%)$, livestock watering $(9.11 \%)$, religious practices $(19.69 \%)$, recreation (11.98\%), fishing (10.97\%) and other activities such as for building $(0.78 \%)$.

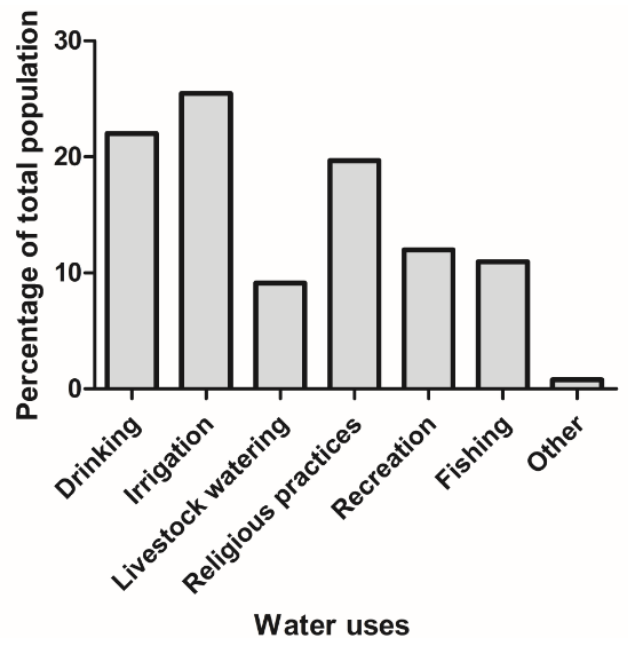

Figure 11. Future proposed uses of the Wonderfonteinspruit 
Figure 12 indicates that more than half of the respondents care about the state of the Wonderfonteinspruit (57.63\%), the Donaldson Dam (70.46\%) as well as the environment surrounding the Wonderfonteinspruit and Donaldson Dam (73.78\%). In particular concern about the state and availability of water for present and future generations was shown $(91.15 \%)$ as well as the quality of water used by the householder and the household members $(89.73 \%)$. When asked what feelings the households of Bekkersdal have towards the Wonderfonteinspruit including the Donaldson Dam 54.07\% indicated that they were unaware of it prior to this questionnaire, $10.37 \%$ viewed it as unimportant, 9.33\% viewed the dam as important, $24.59 \%$ indicated an affinity for the river and $1.63 \%$ indicated that the river makes them happy (Figure 13). An overwhelming $87.80 \%$ of the respondents indicated a willingness to be part of environmental clean-up initiatives in the area of Bekkersdal.

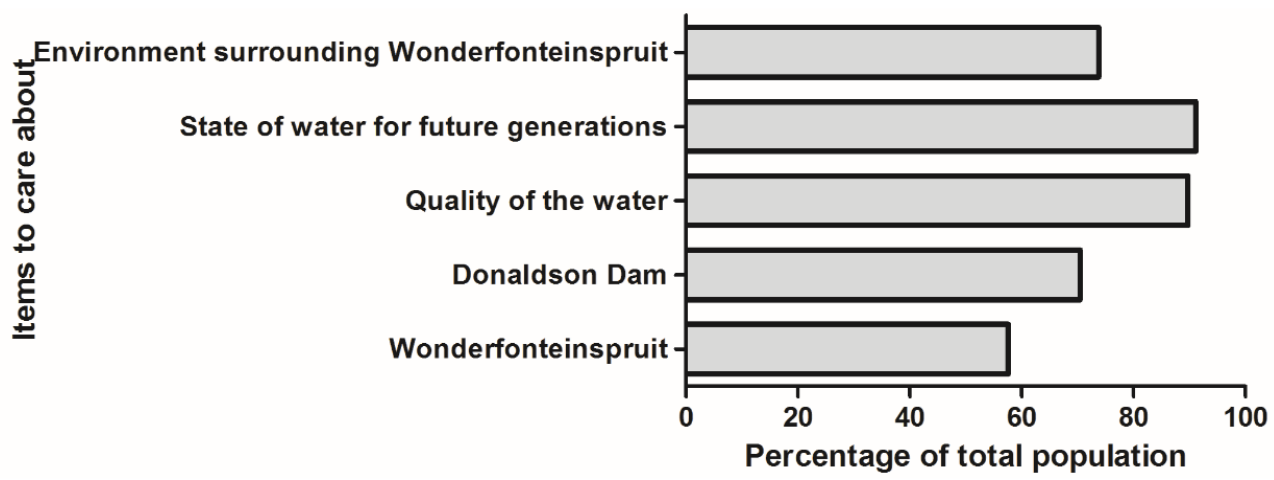

Figure 12. What the people of Bekkersdal care most about

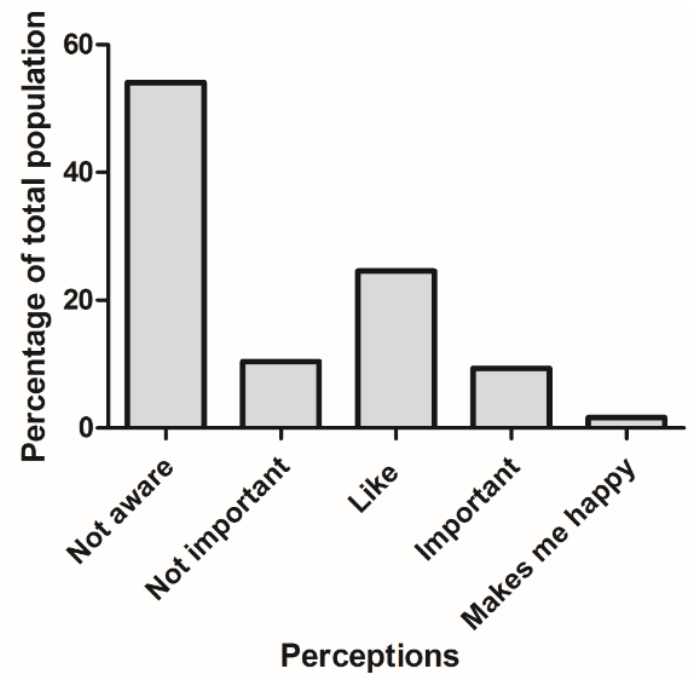

Figure 13. Perceptions of the Bekkersdal people toward the Donaldson Dam

\section{DISCUSSION}

The South African constitution [19], along with a plethora of national and international laws and treaties provide for the protection of the right to sufficient water for every South African citizen, such as demonstrated by the Water Services Act of South Africa [20], the South African National Water Act [21], the World Bank's: "The Human Right to Water" indicating international legal and policy requirements [22] and the South African National Environmental Management Act [23]. Water is considered to be central to upholding human rights such as are enshrined in the Universal Declaration of Human Rights, the Declaration on the Right to Development and the International Covenant on 
Economic, Social and Cultural Rights [22] The United Nations Committee on Economic, Social and Cultural Rights in 2002 issued General Comment No. 15: The Right to Water [24]. It states categorically that all humans have the right to water and that human rights cannot be upheld without access to water.

Despite the absolute right to sufficient drinking water and the need for a certain quantity and quality of water to uphold rights [22] such as the right to life or the right to an environment that is not harmful to human health and wellbeing, a link between poverty and water shortage is apparent [25, 26]. According to the Bloomberg, International Monetary Fund (updated $28^{\text {th }}$ June, 2013) South Africa has the third highest unemployment rate in the world of $25.2 \%$, in future likely to increase with the downturn in South Africa's economy [27]. Some 30.2\% of South Africans and $45.5 \%$ of South African households with at least one member reliant on social grants [28, 29]. This trend of unemployment and reliance on governmental services is shared by the Bekkersdal community where an unemployment rate of $74.30 \%$ was found (Figure 2). The number of dependents within Bekkersdal is by far the majority making up some $64.73 \%$. Furthermore, a $100 \%$ reliance on the municipality to provide water for the Bekkersdal households as their primary water source was found. Despite the indication given that some $1.11 \%$ (Figure 6 ) have no access to water, form the wording of these responses in Table 1 it was deducted that this response of 'no water' indicates that these representatives experienced times where water was unavailable or that taps were too far for them to collect water as these residents nonetheless indicated that they use municipal water as their primary source of water. Bekkersdal can be considered an impoverished or indigent community due to the high unemployment. According to the National Indigent Policy by Municipalities indigent households are those that are unable to access or pay for basic services [30]. According to the Free Basic Services (FBS) policy indigent households have a right to free water service delivery. Many of the complaints regarding water service delivery in Bekkersdal were directed towards payment issues (25.42\%) as can be noted in Figure 6 and one of the reasons identified by the respondents for the strikes in 2013 was because the residents were unwilling and unable to pay for metered taps as can be seen in Table 1. The WLM 2013/14 Annual Report indicates this unwillingness or inability to pay for services as some $80 \%$ of all monies owed to the municipality are owed by residents and $90 \%$ of the debts are from the townships Simunye and Bekkersdal. Taking into consideration the unemployment rate of $30 \%$ and $26 \%$ of households with no income in the Westonaria Local Municipality [17] it was unexpected to see the implementation of metered systems in Bekkersdal and understandable that especially the informal community members were unhappy about paying for services due to their financial constraints. The Free Basic Water Policy as stipulated in the Water Services Act of 1997 furthermore places the demand upon the government to provide a minimum of $6 \mathrm{KL}$ per household per month without charging the consumer [20] has to be provided regardless of an individual being able to provide for the water themselves. However, it must be noted that indigent households must register to benefit from the free service delivery. This has been found by the Centre for Applied Legal Studies to be an inappropriate system [30]. Coupled with the high unemployment rate of $74.30 \%$ is the high cost of clean water if it has to be provided to $64.73 \%$ of dependents (Figure 2). According to the Brita Index (25 th March 2014) on the highest cost of safe water per country South Africa ranks sixth globally.

\section{Issues with water service delivery}

The WHO and the United Nations Children's Fund (UNICEF) stipulate that a potable water source should be within a reasonable distance from the household, that is, no more than $200 \mathrm{~m}$ in an urban environment [31]. The World Bank allows for the water source to be within a reasonable distance which was defined as 15 minutes walking distance 
from the household within rural areas [32]. It is recommended that the definition of a "reasonable distance" should take into consideration the local conditions and most importantly the citizens collecting water should also "not spend a disproportionate time fetching water" $[32,33]$. South Africa's Free Basic Services (FBS) policy stipulates that the water source should be within a $200 \mathrm{~m}$ radius from the household and that a minimum of 6 kilolitres per household per month should be provided [30]. Figure 4 indicates that there is a disparity between what the formal residents' travelling to a water resource experience compared to that of the informal households. Almost without exception $(99.60 \%)$ the formal residents have an average distance of less than 5 minutes to collect water while the majority of the informal residents $(38.27 \%$ ) have to travel more than twenty minutes to collect water. Furthermore, this disparity is again emphasised by the difficulty involved in collecting water as some $45.15 \%$ of the informal households considered collecting water to be difficult while the formal residents once again almost unanimously responded that collecting water was very easy. The differences between the formal and informal residents' responses are to be expected as most formal households have taps within their houses while the informal residents collect water from communal street taps or use the Donaldson Dam.

The water services delivered to the informal settlement thus does not conform to the recommendations provided by the World Bank. To add to this issue $9.28 \%$ of the complaints regarding water services indicated long queues at municipal water taps in which the residents have to wait to collect water (Figure 6). Once again, adding more time to the process of collecting water, some $22.63 \%$ of the complaints were regarding the closing of water services without residents being given prior notice. This resulted in residents having to wait for hours to collect water as can be seen from the quotes in Table 1. While the delay in collecting water may be seen as an inconvenience it becomes a more serious issue if water is limited or inaccessible to stem fire outbreaks as some residents have mentioned (Table 1).

\section{Use of the Wonderfonteinspruit (inclusive of Donaldson Dam)}

In scientific reports the Wonderfonteinspruit is considered to be a highly polluted and modified system, due to mining related discharges [34] resulting in high concentrations of uranium and other dissolved metals in the water and sediments [35]. Studies have even found elevated concentrations of uranium in plants and cattle occurring in the area [36]. The river has only deteriorated further due to the decrease in flow with the recent drought in South Africa, Hanslik et al. [37] indicated that in the presence of point source pollution decreased flow often results in increased eutrophication, algal blooms and decreased dissolved oxygen. Despite its degraded condition it is still utilised by both the people of Bekkersdal [38] and as a tourist site for recreational and professional angling [39]. Some $10.14 \%$ of the Bekkersdal residents make use of the Upper-Wonderfonteinspruit (inclusive of the Donaldson Dam) on a regular basis, from both the formal and informal sections. To clarify this does not exclude these individuals' use of municipal water as their primary source of water, as they make use of the dam water, as a secondary or supplementary source, for either additional activities or when experiencing the aforementioned issues with municipal water services. Those that have used or continue to use Donaldson Dam make use of it most often for drinking and washing as can be seen in Figure 7. Since the water is of a questionable quality it is expected that $11.54 \%$ complained about health effects caused by the use of Donaldson Dam water. The most commonly reported problems are diarrhoea and skin problems. Many households commented that the children would swallow the water when swimming and return home with gastrointestinal problems and skin rashes. Along with the dangers associated with the polluted water, issues regarding drowning and community views also affect the use of the Donaldson Dam. This includes the use of the dam for recreational purposes. Several 
residents explained that they were afraid of the large snake living in Donaldson Dam that damages buildings and leads to drowning. Others explained that their concerns relate to the safety of using the dam and requested both better security and lifeguards.

Donaldson Dam is one of the few natural features nearby Bekkersdal and thus should play a pivotal role in providing a link to the environment and the people of Bekkersdal. The solution is thus not to limit the exposure of Bekkersdal residents to the Wonderfonteinspruit but rather that it should be remediated especially as this link to nature is vital for the wellbeing and health of children and adults. Some residents were of the opinion that the Donaldson Dam may provide entertainment for the youth thus distracting them from unlawful or dangerous activities.

\section{Future water use wants and needs}

Respondents participating in the Bekkersdal questionnaire indicated that if water could be made more readily available $42.60 \%$ would use the water for additional activities. Figure 11 indicates the percentages of water uses which the Bekkersdal residents would utilise from the Wonderfonteinspruit if it was of an acceptable quality. It can be noted that most residents would use the water for irrigation $(25.45 \%)$, drinking water $(22.02 \%)$ and religious practices $(19.69 \%)$. Residents indicated that they would furthermore like to use the dam for recreation (11.98\%) of which it should be noted that adults (aged 18 and older) were the target group of this questionnaire and thus it is expected that many individuals of the younger generation would most likely use the dam far more regularly for recreation, this is further supported by the fact that many parents indicated that their children already make use of the Donaldson Dam for recreation. Some $10.97 \%$ of the respondents indicated that they would like to use the dam for fishing and if properly implemented this can provide opportunities for income generation or a means to feed some households. Livestock watering was another use identified as well as other uses such as using the water for building purposes.

From Figure 7 it is obvious that there is demand within Bekkersdal for water use over and above the water provisions currently available. It is also certain from the questionnaire outcome that the people of Bekkersdal would make use of the Wonderfonteinspruit if it was perceived to be a safer environment. In fact many views expressed by the Bekkersdal residents indicated their desire to use the dam for various activities as can be seen in Figure 11. It is therefore essential when considering the importance of the Wonderfonteinspruit to consider its value not only in terms of current use but also in terms of future use. The rights of future generations should not be compromised for the goals of current generations [40, 41].

\section{Perceptions of the Bekkersdal community toward the Upper-Wonderfonteinspruit}

Bekkersdal has water resources that are shared between the community members especially within the informal section. These shared resources include the communal municipal taps and the Donaldson Dam (the Upper-Wonderfonteinspruit) which are shared between the members of the Bekkersdal community as well as paying visitors to the Donaldson Dam.

According to the perspectives presented by the residents of Bekkersdal it would seem apparent that the majority of the households are invested in improving the state of the Wonderfonteinspruit (inclusive of the Donaldson Dam) and the surrounding environment. Figure 12 indicates that the greater majority of the inhabitants of Bekkersdal care about the Wonderfonteinspruit, the environment surrounding it and the state of water quality for both present and future generations. Finally, some $87.8 \%$ of the respondents indicated their willingness to be involved in environmental clean-up initiatives in their area despite the fact that some $54.07 \%$ of the respondents were ignorant 
of the Wonderfonteinspruit and Donaldson Dam before this questionnaire. Taking into consideration the concern shown by the residents of Bekkersdal it is thus imperative for government and corporate water users of the Wonderfonteinspruit to consult with the community of Bekkersdal as is required by the National Environmental Management Act of 1998 [23] and the National Water Act of 1998 [21]. The principle of participation is summarized by Llamas [2] as including, not avoiding, any individuals in particular the poor from taking part in ensuring their rights are upheld and protected. This sentiment is supported by Bovaird [42] who emphasises the importance of placing communities centrally in decision-making processes such as service delivery decisions.

\section{CONCLUSIONS}

There are limitations with regards to water access within Bekkersdal and some threats to national and international human rights within parts of Bekkersdal. These inadequacies are apparent from both a water service delivery perspective as well as an environmental perspective. The residents at times have to travel more than 20 minutes to collect water, stand in long queues and experience the closing of municipal taps which is in contravention to the guidelines set by the World Bank. If municipal taps are closed without prior notice the residents are unable to plan for this eventuality and have few options for alternative sources especially due to their impoverished state which would impinge upon the requirement set by the National Water Act of South Africa no. 36 of 1998, for the provision of $25 \mathrm{~L}$ of potable water to be provided per day per person. Furthermore, the environmental state of the Upper-Wonderfonteinspruit (inclusive of the Donaldson Dam) poses risks to their health when it is used for activities such as drinking, recreation and washing which threatens their right to health. The degraded condition of the Upper-Wonderfonteinspruit also threatens the right to an environment that is not harmful to their health and wellbeing and one that is sustainably developed for both present and future generations.

The Wonderfonteinspruit is continuously and unnaturally kept flowing by the pumping of underground water from the surrounding mines. During times of drought the Upper Wonderfonteinspruit still flows due to these inputs, therefore despite the poor quality of the water the continuous availability of water in the river system, which would otherwise be a non-perennial river, provides opportunities for use thereof. The mines in the area however are set for closure in the near future with the definite possibility of loss of this input of water into the Wonderfonteinspruit. This can lead to the further deterioration in the living conditions of the residents of Bekkersdal and surrounding communities with the loss of both water and economic opportunities. It is recommended that this baseline study be used to assess the possible impact on communities that mine closure may cause in the surrounding area, as Bekkersdal is typical of the communities within mining areas.

The residents of Bekkersdal have a generally good understanding of the importance of the environment for human health and wellbeing and do perceive the Wonderfonteinspruit to be polluted and dangerous. Nevertheless, there is an overwhelming desire within the respondents to improve their situation with regards to water use and use of the Wonderfonteinspruit and the surrounding environment. This should not be neglected by the relevant organs of state and corporate users of the Wonderfonteinspruit especially as water is a shared common good, despite the indication that this concept has been neglected within the Wonderfonteinspruit catchment.

One of the key outcomes of the research was to report back on the findings to the community in public forums that invite discussion and debate, building on this however is the need to involve governmental and industrial role-players to be involved in the discussions at the same level as the communities. 


\section{RECOMMENDATIONS}

Several recommendations to work towards a solution to the water supply issues at Bekkersdal can be drawn from this study. The first recommendation relates to improved communication between the residents and the municipality: all residents should be made aware of who to contact should there be any water related concerns. Secondly, water infrastructure maintenance can be improved through basic education programs at schools such that children are taught from a young age the importance of not breaking the infrastructure and saving water. Furthermore, economic opportunities exist for enterprising community members, such as offering inexpensive water transfer services to individuals through the use of wheelbarrows, or, through group-funding for larger water carriers. Though water is a basic right as per the South African Constitution and therefore the Government's responsibility to supply to its citizens, it is also the responsibility of the citizens to aid the Government in improving water service delivery.

These recommendations however only address the physical water service delivery issues, while the greater issues of indigent households and polluted water resources requires a multi-party input. The most vital element is to bring all role players into the same room. It is therefore recommended that a Water User Association be established for the Upper Wonderfonteinspruit as can be instituted per the National Water Act [21]. The Act defines the Water User Association as units that: "Operate at a restricted localised level, and are in effect co-operative associations of individual water users who wish to undertake water related activities for their mutual benefit" [21]. Membership to these associations would allow for all water users to collectively address issues and inform both government and private water users as to the social responsibilities that should be fulfilled towards the communities and each other.

\section{ACKNOWLEDGEMENT}

This research, as part of a community engagement project, was made possible with funding awarded from 2013-2016 by the National Research Foundation of South Africa. The opinions expressed in the article, are that of the authors and not the NRF. Enquiries: Project leader, Elize.vanEeden@nwu.ac.za

\section{REFERENCES}

1. Falkenmark, M. and Folke, C., The Ethics of Socio-ecohydrological Catchment Management: Towards Hydrosolidarity, Hydrology and Earth System Sciences, Vol. 6, No. 1, pp 1-9, 2002, https://doi.org/10.5194/hess-6-1-2002

2. Llamas, R., Ethical Considerations in Water Management Systems, Water Nepal, Vol. 9/10, No. 1/2, pp 13-27, 2003, https://doi.org/10.3126/wn.v10i1.90

3. Rahaman, M. M. and Varis, O., Integrated Water Resources Management: Evolution, Prospects and Future Challenges, Sustainability: Science, Practice \& Policy, Vol. 1, No. 1, pp 15-21, 2005.

4. Amery, H. A., Islamic Water Management, Water International, Vol. 26, No. 4, pp 481-489, 2009, https://doi.org/10.1080/02508060108686949

5. UN General Assembly, Universal Declaration of Human Rights, 1948, 217 A (III), http://www.refworld.org/docid/3ae6b3712c.html, [Accessed: 13-February-2015]

6. Donnelly, J., Universal Human Rights in Theory and Practice ( $3^{\text {rd }}$ ed.), Cornell University Press, New York, USA, pp 129-132, 2013.

7. Moench, M., Dixit, A. and Caspari, E., Water, Human Rights and Governance: Issues, Debates and Perspectives, Water Nepal, Vol. 9/10, No. 1/2, pp 1-9, 2003.

8. Kemp, D., Bond, C. J., Franks, D. M. and Cote, C., Mining, Water and Human Rights: Making the Connection, Journal of Cleaner Production, Vol. 18, No. 15, pp 1553-1562, 2010, https://doi.org/10.1016/j.jclepro.2010.06.008 
9. Pakina, A. A., Green Economy's Prospects in Russia: Case of Baikal Area, Journal of Sustainable Development of Energy, Water and Environment Systems, Vol. 2, No. 2, pp 139-151, 2014, https://doi.org/10.13044/j.sdewes.2014.02.0013

10. European Environment Agency (EEA), Water Resources across Europe - Confronting Water Scarcity and Drought, EEA Report No. 2/2009, Copenhagen, Denmark, 2009.

11. Alexander, P., A Massive Rebellion of the Poor, Mail and Guardian April 13, 34 pp, 2012.

12. Van Eeden, E. S., Draft Project Report on Bekkersdal, Profiling another 'Bekkersdal Marathon': The Longwinded Service delivery woes of a Community in the West Rand mining Region of South Africa, pp 1-48, 2014.

13. Tau, S., Bekkersdal Leader warns of 'Black Christmas', The Citizen, 2013.

14. Sithole, H., Bekkersdal Saga continues, SABC, 2014.

15. Sosibo, K., State Left with Bekkersdal Municipal Mop-up, Mail \& Guardian, 2013.

16. Westonaria Local Municipality (WLM), Draft Annual Report 2013/14, 2014.

17. Heaslip, E., Costello, G. J. and Lohan, J., Assessing Good-practice Frameworks for the Development of Sustainable Energy Communities in Europe: Lessons from Denmark and Ireland, Journal of Sustainable Development of Energy, Water and Environment Systems, Vol. 4, No. 3, pp 307-319, 2016, https://doi.org/10.13044/j.sdewes.2016.04.0024

18. Ellis, S. M. and Steyn, H. S., Practical Significance (Effect Sizes) versus or in Combination with Statistical Significance (P-values), Management Dynamics, Vol. 12, No. 4, pp 51-53, 2003.

19. Republic of South Africa (RSA), Constitution of the Republic of South Africa (Act No. 108 of 1996), Government Gazette, South Africa (17678), 1996.

20. Republic of South Africa (RSA), Water Services Act (Act No. 108 of 1997), Government Gazette, South Africa 390 (18522), 1997.

21. Republic of South Africa (RSA), National Water Act (Act No. 36 of 1998), Government Gazette, South Africa 398 (19182), 1998.

22. Salman, S. M. A. and McInerney-Lankford, S., The Human Right to Water: Legal and Policy Dimensions, Law Justice and Development Series No. 30229, The World Bank, Washington, 2004, https://doi.org/10.1596/0-8213-5922-3

23. Republic of South Africa (RSA), National Environmental Management Act (Act No. 107 of 1998), Government Gazette, South Africa 540 (33306), 1998.

24. Economic and Social Council of the United Nations, General Comment No. 15: The Right to Water (Arts. 11 and 12 of the Covenant), 2002.

25. Molle, F. and Mollinga, P., Water Poverty Indicators: Conceptual Problems and Policy Issues, Water Policy, Vol. 5, pp 529-544, 2003.

26. Kummu, M., Ward, P. J., de Moel, H. and Varis, O., Is Physical Water Scarcity a new Phenomenon? Global Assessment of Water Shortage over the last Two Millennia, Environmental Research Letters, Vol. 5, No. 3, pp 1-10, 2010, https://doi.org/10.1088/1748-9326/5/3/034006

27. Bloomberg, Highest Unemployment: Countries, http://www.bloomberg.com/visualdata/best-and-worst//highest-unemployment-countries,

2013, [Accessed: 12-January-2015]

28. SAinfo, Social Grants reach almost One-third of South Africans, 2013, http://www.southafrica.info/about/social/grants-190614.htm\#.VLNsQSuUc9w, [Accessed: 12-January-2015]

29. Statistics South Africa, Westonaria Key Statistics, http://beta2.statssa.gov.za/?page_id=993\&id=westonaria-municipality, 2014 , [Accessed: 12-January-2015]

30. South African Human Rights Commission (SAHRC), Report on the Right to access Sufficient Water and decent Sanitation in South Africa: 2014, South African Human Rights Commission, Johannesburg, Republic of South Africa, 2014. 
31. World Health Organisation (WHO) and United Nations Children's Fund (UNICEF), Global Water Supply and Sanitation Assessment Report, WHO Press, France, 2000.

32. Langford, M. and Kok, A., The Right to Water (Brand, D. and Heyns, C., eds.), Socioeconomic Rights in South Africa, Pretoria University Law Press, pp 190-208, Pretoria, Republic of South Africa, 2005.

33. Heleba, S., Access to Sufficient Water in South Africa: How Far have we come? Research Paper, Community Law Centre, University of the Western Cape, Cape Town, Republic of South Africa, 2009.

34. Coetzee, H., (Compiler), An assessment of Sources, Pathways, Mechanisms and Risks of Current and Potential Future Pollution of Water and Sediments in Gold-mining Areas of the Wonderfonteinspruit Catchment, WRC Report No. 1214/1/06, 266 pp, Pretoria, Republic of South Africa, 2004.

35. Winde, F., Uranium Pollution of Water Resources in Mined-out and Active Goldfields of South Africa - A Case Study in the Wonderfonteinspruit Catchment on Extent and Sources of U-contamination and associated Health Risks, Abstracts of the International Mine Water Conference, Pretoria, Republic of South Africa, October 19-23, 2009.

36. Hamman, D., A Holistic View on the Impact of Gold and Uranium mining on the Wonderfonteinspruit, M.Sc. Thesis, North-West University, Potchefstroom, Republic of South Africa, 2012.

37. Hanslik, E., Maresova, D., Juranova, E. and Vlnas, R. Dependence of Selected Water Quality Parameters on Flow Rates at River Sites in the Czech Republic, Journal of Sustainable Development of Energy, Water and Environment Systems, Vol. 4, No. 2, pp 127-140, 2016, https://doi.org/10.13044/j.sdewes.2016.04.0011

38. Dennis, R., Dennis, I., Hamman, D. and Van Rensburg, L., Cattle consumption Model for the Wonderfonteinspruit Related to Human Health Risk, Agricultural Journal, Vol. 8, No. 3, pp 144-151, 2013, https://doi.org/10.3923/aj.2013.144.151

39. African Gold Carp Fishing Adventures, Donaldson Dam, http://www.africangold.info/donaldson.htm, 2014, [Accessed: 20-April-2015]

40. Weiss, E. D., Our Rights and Obligations to Future Generations for the Environment, The American Journal of International Law, Vol. 84, No. 1, pp 198-207, 1990, https://doi.org/10.2307/2203020

41. Stein, R., Water Law in a Democratic South Africa: A Country Case Study examining the Introduction of a Public Rights System, Texas Law Review, Vol. 83, No. 7, pp 2167-2183, 2005.

42. Bovaird, T., Beyond Engagement and Participation: User and Community Coproduction of Public Services, Public Administration Review, Vol. 67, No. 5, pp 846-860, 2007, https://doi.org/10.1111/j.1540-6210.2007.00773.x 